\title{
Amonização da Quirera de Milho com Alta Umidade ${ }^{1}$ \\ Aureliano José Vieira Pires ${ }^{2}$, Rasmo Garcia ${ }^{3}$, Paulo Roberto Cecon ${ }^{4}$, José Neumam Miranda Neiva ${ }^{5}$, Patrícia Sarmento ${ }^{6}$
}

RESUMO - O objetivo deste trabalho foi verificar o efeito da amonização sobre teor de proteína bruta (PB), retenção de nitrogênio (RN), teor de matéria seca (MS), conservação, constituintes da parede celular e digestibilidade in vitro da matéria seca (DIVMS) da quirera de milho com alta umidade (25\%). Quatro níveis de amônia anidra (0,1,2 e 3\%) e cinco períodos de aeração ( $0,7,14,21$ e 28 dias) foram estudados em delineamento inteiramente ao acaso, em esquema de parcelas subdivididas. Os teores de PB da quirera aumentaram (10,3; 14; 15,2; e 16,2\%) com os crescentes dos níveis amônia anidra (0, 1, 2 e 3\%). A RN diminuiu, 61,9; 39; e 31,2\%, para os níveis de 1, 2 e 3\% de amônia anidra, respectivamente. O teor de MS reduziu com o aumento dos níveis de amônia anidra $(81,0,77,7,77,0$ e 78,0\%) e dos períodos de aeração $(74,2 ; 75,8 ; 78,9 ; 80,3 ;$ e $80,7 \%)$. A RN (52,2 para 38,9\%) e os teores de PB $(14,7$ para $13,5 \%)$ diminuíram com o aumento do período de aeração, respectivamente, no período de 0 a 28 dias. Houve a presença de fungos para os níveis de 0 e $1 \%$ de amônia anidra, associados a temperaturas mais altas. Os teores de fibra em detergente acido $(5,6 \%)$ e celulose $(4,5 \%)$ permaneceram inalterados, tanto para os niveis de amônia anidra, quanto para períodos de aeração. Os teores de fibra em detergente neutro $(22,7 ; 22,8 ; 18,5 ;$ e 14,8\%) e hemicelulose $(17,0 ; 17,3 ; 12,7$ e 9,2\%) reduziram para os níveis de $0,1,2$ e $3 \%$ de amônia anidra, respectivamente. A DIVMS (88,5; 89,8; 90,3; e 90,8 $\%)$ da quirera de milho melhorou com o aumento dos níveis de amônia anidra $(0,1,2$ e 3\%).

Palavras-chave: amônia, conservação, digestibilidade, quirera de milho, umidade

\section{Ammoniation of Cracked Corn with High Moisture}

\begin{abstract}
The objective of this work was to verify the effect of ammoniation on the contents of crude protein (CP), nitrogen retention (NR), dry matter (DM) content, preservation, cell wall constituents and in vitro dry matter disappearance (IVDMD) of cracked corn with high moisture (25\%). Four levels of anhydrous ammonia (0, 1, 2 and 3\%) and five aeration periods $(0,7,1421$, and 28 days) were studied using a completely randomized design, in a split plot design. The contents of cracked corn CP increased $(10.3,14,15.2$ and $16.7 \%)$ with increasing anhydrous ammonia levels $(0,1,2$ and 3\%) respectively. The CP NR decreased, $61.9,39$ and $31.2 \%$, for the levels 1,2 and 3 of anhydrous ammonia, respectively. The DM content decreased with increase of anhydrous ammonia levels $(81.0,77.7,77.0$ and $78,0 \%)$ and with the increase of aeration periods $(74.2,75.8,78.9,80.3$ and $80.7 \%)$. The NR (52.2 to $38.9 \%$ ) and CP (14.7 to $13.5 \%$ ) decreased with increasing of aeration periods, respectively, at the period from 0 to 28 days. There was a fungi presence for levels of 0 and $1 \%$ of anhydrous ammonia, associated with higher temperature. The acid detergent fiber content $(5.6 \%)$ and cellulose (4.5\%) maintained unaltered, such as for anhydrous ammonia levels, as for aeration periods. The contents of neutral detergent fiber $(22.7,22.8,18.5$ and 14.8\%) and hemicellulose (17.0, 17.3, 12.7 and 9.2\%) decreased in the levels of $0,1,2$, and $3 \%$ of anhydrous ammonia, respectively. The IVDMD $(88.5,89.8,90.3$ and 90.8$)$, of cracked corn improved with the increase of the anhydrous ammonia levels $(0,1,2$ and $3 \%)$.
\end{abstract}

Key Words: ammonia, preservation, digestibility, cracked corn, moisture

\section{Introdução}

A quantidade de subprodutos, no Brasil, é muito grande, e as principais limitações nutricionais para a utilização de resíduos agrícolas e restos de cultura na alimentação de ruminantes deve-se, em geral, aos elevados conteúdos dos inibidores da digestão ou fatores antiqualitativos (lignina, compostos fenólicos) e aos baixos valores de compostos nitrogenados, minerais e energia disponível nesses resíduos (GARCIA, 1992).

O milho, em regiões de grande produção, é colhido com teor de umidade elevado (25\% umidade), visando à diminuição de perdas de campo.

A quirera, cujo teor de $\mathrm{PB}$ pode variar de 6 a $12 \%$, é um subproduto proveniente do beneficiamento in-

1 Parte da Tese apresentada à Universidade Federal de Viçosa para obtenção do título de M.S. do primeiro autor.

2 Professor do DTRA da Universidade Estadual do Sudoeste da Bahia, Itapetinga, BA, doutorando na UFV.

${ }^{3}$ Pesquisador do CNPq, Departamento de Zootecnia da Universidade Federal de Viçosa, Viçosa, MG.

${ }^{4}$ Professor do Departamento de Informática da Universidade Federal de Viçosa, Viçosa, MG.

${ }^{5}$ Professor do Departamento de Zootecnia da Universidade Federal do Ceará, Fortaleza, CE.

${ }^{6}$ Mestranda em Zootecnia na Escola Superior de Agricultura Luiz de Queiroz Piracicaba, SP. 
dustrial do grão de milho. É composta, em sua maior parte, de milho quebrado, contendo certa quantidade da parte embrionária, palha, sabugo, além de sementes de plantas invasoras; entretanto, é obtida com teor de umidade próximo ao do milho (25\%), necessitando de secagem ou conservação com tratamentos químicos, para que não ocorra perda deste material.

A maioria das pesquisas a respeito de amonização de forragens, subprodutos da agroindústria e restos de cultura em geral tem mostrado que a amonização, geralmente, promove alterações físico-químicas nos constituintes da parede celular, além de possuir propriedade fúngica, que, ao ser aplicada em forragens com alta umidade, evita o desenvolvimento de fungos e eleva o teor de PB.

Os trabalhos, em sua maior parte, têm mostrado decréscimo consistente nos teores de fibra em detergente neutro (FDN) e hemicelulose, quando se aumentam as doses de amônia, enquanto os teores de fibra em detergente ácido (FDA), celulose e lignina têm sido constantes.

OLIVEROS et al. (1993), pesquisando pés de milho contendo $65 \%$ de MS, tratados com $3 \%$ de amônia anidra, 5,6\% de uréia, 4,0\% de hidróxido de cálcio, $3 \%$ de amônia anidra mais $4 \%$ de hidróxido de cálcio e $5,6 \%$ de uréia mais $4,0 \%$ de hidróxido de cálcio, armazenados durante 14 dias, verificaram redução nas frações de FDN e hemicelulose, sendo mais pronunciada nos tratamentos em que a amônia anidra esteve presente. Entretanto, para as frações de FDA e celulose, não foram observadas diferenças entre os tratamentos.

FERREIRA (1989), aplicando doses de 0, 2 e 4\% de amônia anidra em feno de aveia com alta umidade, observou que os teores de FDN e hemicelulose reduziram, à medida que se elevavam as doses de amônia, o que não foi observado para celulose e lignina, as quais ficaram com teores constantes.

Segundo Mason et al. (1988), citados por GOTO et al. (1993), o aumento da digestibilidade de forragens amonizadas, também, tem sido atribuído à diminuição dos teores de fatores antiqualitativos, como compostos fenólicos e grupo acetil. A redução dos compostos fenólicos e do grupo acetil pela amônia resulta em correlação positiva com a digestibilidade, o que ocorre em razão desses compostos serem tóxicos aos microrganismos ruminais.

Ao trabalhar com feno de alfafa (Medicago sativa L.), CAMPOS (1994) aplicou quatro doses de amônia anidra ( $0 ; 1 ; 1,5$; e 2\%, base MS) em combinação com três períodos de amonização $(14,21$ e 28 dias), observando o desenvolvimento de fungos para os fenos que receberam as doses de 0 e $1 \%$ de amônia anidra. Porém, para as doses de 1,5 e $2 \%$, esse fato não foi constatado.

Os resultados no aumento do teor de proteína bruta, em materiais amonizados, têm apresentado grande variação, que pode ser atribuída a fatores como quantidade de amônia aplicada, período de amonização, temperatura ambiente, umidade e qualidade do material tratado.

TEIXEIRA (1990) relatou aumentos do teor de proteína bruta em taxas de 159,8 e $273,3 \%$, para palha de milho mais sabugo, e 61,6 e 105,7\%, para o capimelefante (Penninsetum purpureum, Schum), ambos tratados com doses de 1,5 e 3,0\% de amônia anidra, respectivamente, comparados ao controle.

PAIVA (1992) verificou resultados semelhantes, quando utilizou palhada de milho. Os tratamentos com amônia promoveram incrementos do teor de $\mathrm{N}$ total na palhada de milho, em função das doses de amônia aplicadas e de aumentos dos períodos de amonização. As elevações dos teores de $\mathrm{N}$ total variaram de $130,6 \%$, para o tratamento com $2 \%$ de amônia anidra e sete dias de período de amonização, a 218,4\%, para o tratamento com $4 \%$ de amônia anidra e 35 dias de período de amonização. A retenção de nitrogênio na palhada de milho foi menor quando a dose de amônia se elevou de 2 para $4 \%$, o que acarretou incremento na retenção de nitrogênio na palhada de milho, principalmente na tratada com $2 \%$ de amônia anidra.

A maioria dos trabalhos com amonização mostra que, à medida que se aumentam as doses de amônia, a quantidade de nitrogênio recuperado diminui. BROWN et al. (1987) relataram retenções de nitrogênio da ordem de 50,6; 34,1; e 29,6\%, para a aplicação das respectivas doses de 2,3 e $4 \%$ de amônia anidra em hemartria (Hemarthria altissima).

Os objetivos deste trabalho foram verificar a eficiência da amônia anidra na conservação da quirera de milho com alta umidade e observar possíveis alterações dos compostos nitrogenados e do teor de matéria seca.

\section{Material e Métodos}

O experimento foi conduzido no Departamento de Zootecnia, da Universidade Federal de Viçosa, em Minas Gerais.

A quirera, resíduo do beneficiamento industrial do grão de milho, usada no experimento foi composta por 
1188 Rev. bras. zootec.

grãos de milho quebrados, pequenos fragmentos de palha e sabugo, sementes de plantas invasoras da cultura de milho e pequena quantidade da parte embrionária do milho, com teor de proteína bruta de $9,8 \%$.

Quinze horas antes de ser submetida aos tratamentos, foi adicionada água à quirera, elevando-se a umidade de 14 para $25 \%$, a qual é próxima a obtida, por ocasião do processamento do grão de milho logo após a colheita.

As variáveis proteína bruta $(\mathrm{PB})$, retenção de nitrogênio (RN), fibra em detergente neutro (FDN), fibra em detergente ácido (FDA), celulose, hemicelulose e digestibilidade in vitro da matéria seca (DIVMS) foram estudadas considerando-se o esquema de parcelas subdivididas, tendo na parcela as doses de amônia anidra de $0 ; 1 ; 2$; e 3\%, base matéria natural $(\mathrm{MN})$, ou $0 ; 1,3 ; 2,7$; e $4 \%$ na $\mathrm{MS}$, e na subparcela, os períodos de aeração $(0,7,14,21$ e 28 dias), em delineamento inteiramente casualizado com três repetições.

Os resultados foram interpretados por meio de análise de variância e regressão, a 5\% de probabilidade.

A escolha do melhor modelo foi realizada com base na significância dos coeficientes da regressão, utilizando-se o teste "t" de Student a 5\% de probabilidade e no coeficiente de determinação.

As análises estatísticas foram realizadas utilizando-se o programa SAEG (Sistema de Análises Estatística e Genética), desenvolvido na UFV.

A amônia anidra foi adicionada ao material (quirera) 15 horas após reconstituição da umidade desejada (25\%). Foram armazenados cerca de $100 \mathrm{~kg}$ de quirera em silos-manilha de concreto com o fundo vedado, com diâmetro de 0,6 x 1,0 m de altura. Utilizaram-se canos de PVC perfurados de 1/2", introduzidos perpendicularmente ao fundo das manilhas para se fazer aplicação. Após o enchimento das manilhas com a quirera, houve cobertura com lona plástica, que foi vedada com massa corrida, fita plástica adesiva e borracha, em volta do silo, para melhor aderência, ficando, apenas, a ponta do cano de PVC do lado de fora, para conexão da mangueira que estava ligada ao botijão de amônia; em seguida, fez-se a aplicação da amônia anidra.

Para proceder à amonização nas doses de 1, 2 e 3\%, utilizou-se um cilindro contendo $60 \mathrm{~kg}$ de amônia anidra.

Após um período de 42 dias de armazenamento, as manilhas foram abertas e o material correspondente a cada tratamento foi colocado em sacos plásticos, que foram levados a um galpão coberto, onde permaneceram em aeração por 28 dias, sendo as amostras coletadas a cada sete dias. Dessa forma, as coletas foram feitas nos períodos de $0,7,14,21 \mathrm{e}$ 28 dias de aeração e acondicionadas em sacos plásticos, que foram armazenados em câmara fria, a fim de evitar possíveis reações em virtude da umidade e, ou, da amônia aplicada.

Após a moagem, as amostras foram colocadas em vidros, identificados, e mantidas sob refrigeração até o momento de serem submetidas às análises químico-bromatológicas.

As análises de nitrogênio total (NT), MS, fibra em detergente neutro (FDN), fibra em detergente ácido (FDA), celulose, hemicelulose, lignina e DIVMS foram feitas de acordo com os procedimentos descritos por SILVA (1990).

Os dados percentuais para retenção de nitrogênio $(\mathrm{RN})$, na quirera amonizada em relação à nãoamonizada, foram obtidos com base no procedimento adotado por PAIVA (1992) e CAMPOS (1994), utilizando-se a seguinte fórmula:

$$
\begin{aligned}
& \mathrm{RN}(\%)=\left[(\% \mathrm{NA}-\mathrm{NB}) \div\left(\% \mathrm{NH}_{3} \times 0,8224\right)\right] \times 100 \\
& \quad \text { em que }
\end{aligned}
$$

$\mathrm{RN}(\%)=$ retenção de nitrogênio expressa em porcentagem do nitrogênio adicionado;

$\% \mathrm{NA}=$ porcentagem de $\mathrm{N}$ total no material amonizado;

$\% \mathrm{NB}=$ porcentagem de $\mathrm{N}$ total no material não-amonizado;

$\% \mathrm{NH}_{3}=$ porcentagem de amônia anidra utilizada no tratamento; e

$0,8224=$ valor percentual de $\mathrm{N}$ na amônia anidra.

As temperaturas foram tomadas para se observar o efeito da amônia anidra sobre a preservação, tendo como fator indicador a elevação da temperatura resultante da fermentação da quirera nos períodos de aeração (7, 14, 21 e 28 dias), verificando-se, também, a estabilização do material. Foi utilizado um termômetro digital. As leituras referentes ao período de aeração foram tomadas a cada sete dias, sendo feitas sempre às $9 \mathrm{~h}$, no momento de cada coleta das amostras.

\section{Resultados e Discussão}

Verificou-se efeito $(\mathrm{P}<0,01)$ de doses amônia, períodos de aeração e interação entre doses de amônia e períodos de aeração, para PB e RN.

Os teores médios de PB, nas doses de $0,1,2$ e $3 \%$ de amônia, foram, respectivamente, 10,3; 14; 15,2; e $16,2 \%$, e para os períodos de aeração, $0,7,14,21$ e 28 dias, 14,$7 ; 14,2 ; 13,7 ; 13,6 ;$ e 13,5, respectivamente.

Nas Figuras 1 e 2, verifica-se, respectivamente, a 
variação do teor de PB (17,9\%), em função das doses de $\mathrm{NH}_{3}$ dentro de cada período de aeração e dos períodos de aeração dentro de cada dose de amônia. Observa-se na Figura 1 maior teor de PB para a combinação da dose de $3 \%$ de amônia com o período zero dia de aeração, o que ocorreu em virtude do nitrogênio não-protéico aplicado na quirera em níveis crescentes, que foi determinado na análise de nitrogênio total utilizada no cálculo do teor de PB. Entretanto, na Figura 2, verifica-se pequena queda no teor de PB do material amonizado, com o aumento do teor do período de aeração. Isso ocorre em virtude da perda de nitrogênio por volatilização, que foi maior para o níveis mais elevados.

Aumentos no teor de PB, com adição de N nãoprotéico, foram verificados por FAHMY e KLOPFENSTEIN (1994), ao utilizarem silagem de pé de milho contendo $40 \%$ de MS e adicionarem uréia. Foram detectados aumentos no teor de PB da ordem de $156,3 \%$ e, ao adicionarem uréia mais $5 \% \mathrm{SO}_{2}$, incremento de $226,7 \%$. Os teores de PB para silagem controle, silagem mais uréia e silagem mais uréia mais SO2 foram de 5,2; 13,4; e 17,1\%, respectivamente.

Nas Figuras 3 e 4, pode-se verificar a retenção de nitrogênio $(\mathrm{RN})$, em função das doses de amônia dentro de cada período de aeração e dos períodos de aeração dentro de cada dose de $\mathrm{NH}_{3}$. Observa-se, na Figura 3, que o comportamento dos períodos de aeração foi semelhante, sendo que os menores valores de RN foram verificados para o período de

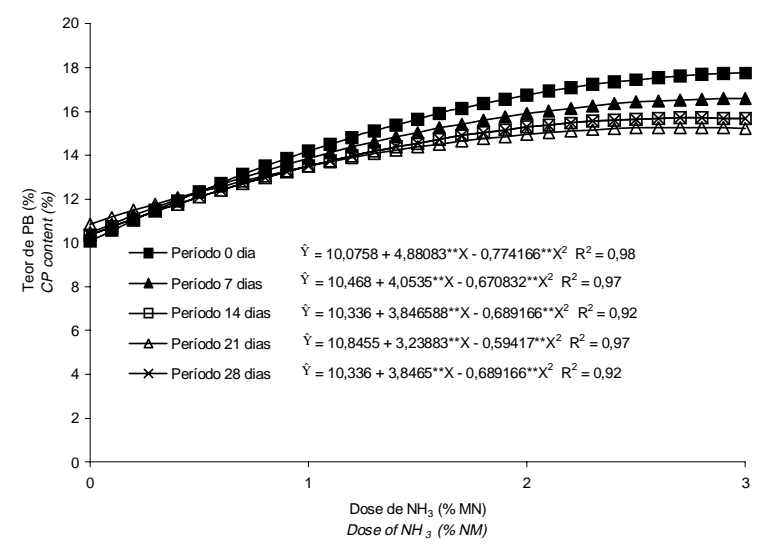

Figura 1 - Estimativas dos teores médios de proteína bruta (PB), na quirera de milho com alta umidade, em função de doses de amônia anidra dentro de cada período de aeração.

Figure 1 - Estimates of crude protein $(C P)$ average contents in the cracked corn with high moisture in function of doses of anhydrous ammonia within each aeration period. aeração maior (28 dias) e maior RN para o menor período (0 dia). Entretanto, na Figura 4, nota-se que maiores diferenças ocorreram com as doses de amônia. A dose de $1 \%$ associado ao período zero foi o que teve maior RN, a qual diminuiu com o aumento dos períodos de aeração. A dose que apresentou maior perda de N, ou seja, menor RN, foi a aplicação de $3 \%$ de amônia, associado ao período de 28 dias.

A RN na quirera foi, em média, 61,9; 39,0; e $31,2 \%$ para as doses de 1,2 , e $3 \%$ de amônia, e 52,2; 46,$8 ; 42,6 ; 39,7$; e $38,9 \%$, para os respectivos períodos de aeração de $0,7,14,21$ e 28 dias.

SAENGER et al. (1982) verificaram que, para o pé de milho tratado com doses de 2 e $3 \%$ de amônia anidra, a retenção de $\mathrm{N}$ foi reduzida com o aumento das doses.

SRIVASTAVA e MOWAT (1980) encontraram retenção de $\mathrm{N}$ na ordem de $35 \%$, quando utilizaram dose de $2 \%$ de amônia anidra em espiga de milho contendo $28 \%$ de umidade, o que está de acordo com os dados encontrados para a quirera.

Verificou-se efeito significativo $(\mathrm{P}<0,01)$ das doses de amônia, dos períodos de aeração e da interação de doses de amônia com períodos de aeração para o conteúdo de matéria seca (MS). Nas Figuras 5 e 6, observa-se a variação da MS, em função das doses de amônia dentro de cada período de aeração e dos períodos de aeração dentro de cada nível de amônia.

O valor médio de MS da quirera de milho com alta umidade, antes de ser submetida aos tratamentos, foi

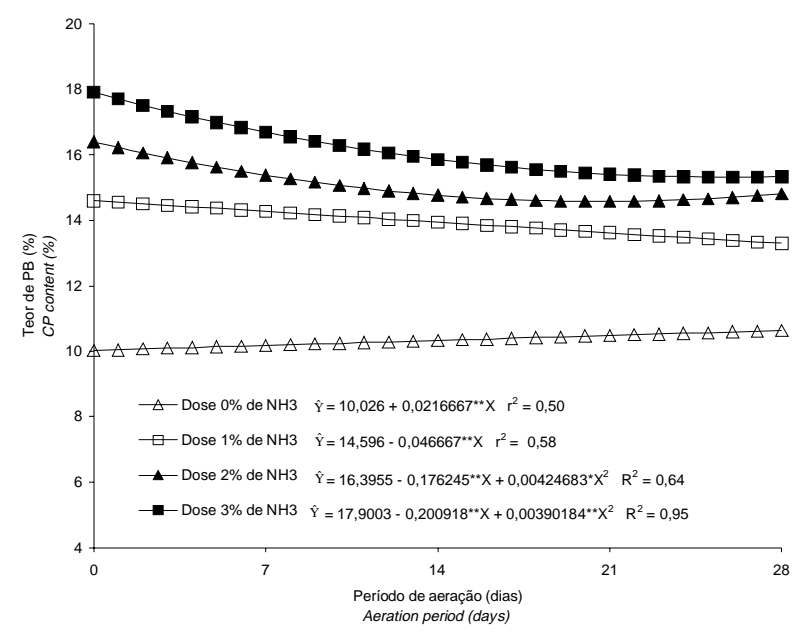

Figura 2 - Estimativas dos percentuais médios de proteína bruta (PB), na quirera de milho com alta umidade, em função dos períodos de aeração.

Figure 2 - Estimates of crude protein (CP) average contents crude protein $(C P)$ in the cracked corn with high moisture in function of aeration periods. 


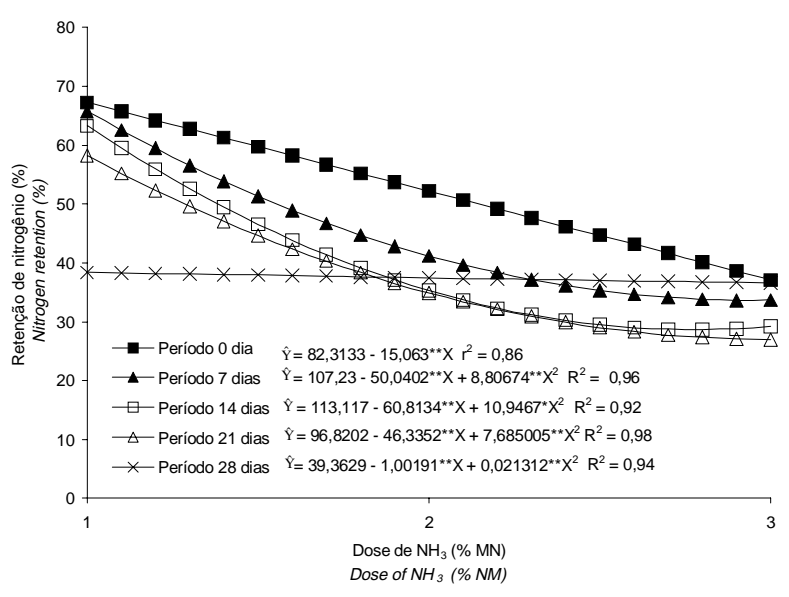

Figura 3 - Estimativas dos percentuais médios de retenção de nitrogênio (RN), na quirera de milho com alta umidade, em função de doses de amônia anidra.

Figure 3 - Estimates of average percentage of nitrogen retention $(N R)$ in the cracked corn with high moisture in function of doses of anhydrous ammonia.

de 74,3\%. Com o aumento das doses de amônia, verificou-se maior constância na matéria seca, o que pode estar associado ao não-desenvolvimento de fungos ou à fermentação, que aumentam a temperatura e, conseqüentemente, reduzem o teor de umidade. À medida que se elevou o período de aeração, o teor de MS, também, aumentou em todos as doses de amônia. Porém, esse aumento foi menor para as doses de 2 e $3 \%$ de $\mathrm{NH}_{3}$ e maior para os níveis de 0 e $1 \%$. Esse fato ocorreu em razão de o material ficar exposto ao ambiente, o que permitiu contínuo processo de desidratação, associado à fermentação que foi verificada por elevação de temperatura (Figura 7). Portanto, as doses de 2 e $3 \%$ de amônia mostraram-se eficientes, por evitarem fermentação e, conseqüentemente, perdas do teor de umidade (Figuras 5 e 6).

A estabilidade do material tratado, em função das doses de amônia, fica melhor evidenciada com a variação dos teores de MS nos períodos de aeração. Nota-se, portanto, que os teores médios de MS, para as doses de $0,1,2$ e $3 \%$ de amônia anidra, variaram de 74,0 a $84,8 \%, 73,9$ a $81,1 \%, 74,5$ a $79,2 \%$ e 74,5 a $78,4 \%$, respectivamente.

Por meio de observações visuais, verificou-se que a conservação da quirera de milho, com alta umidade, ocorreu, apenas, para as doses de 2 e $3 \%$ de amônia anidra, enquanto as demais doses apresentaram sinais de fungos. Estes resultados estão de acordo com vários outros trabalhos. A eliminação completa de fungos e a estabilidade do número de

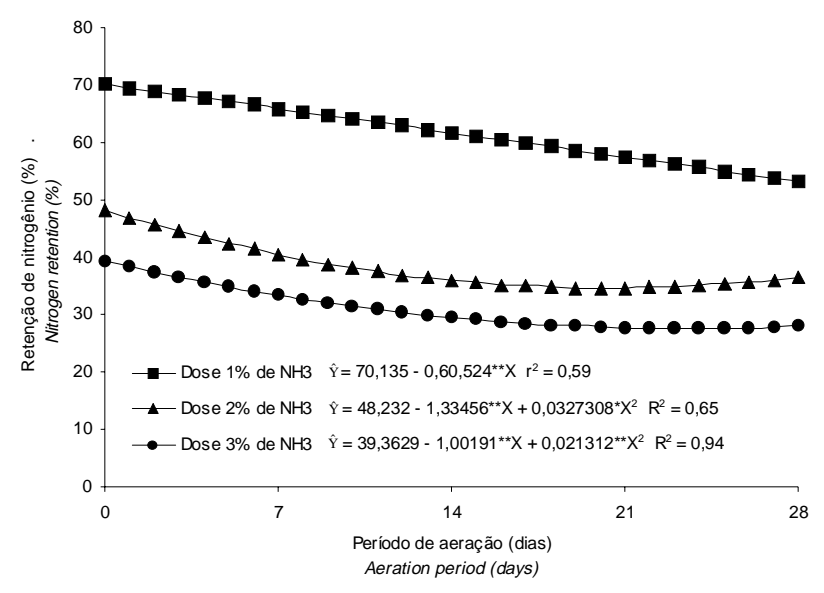

Figura 4 - Estimativas dos percentuais médios de retenção de nitrogênio (RN), na quirera de milho com alta umidade, em função dos períodos de aeração.

Figure 4 - Estimates of average percentage of nitrogen retention (NR) in the cracked corn with high moisture, in function of aeration periods.

colônias de bactérias foram observadas por BOTHAST et al. (1973), ao aplicarem $2 \%$ de $\mathrm{NH}_{3}$ em grãos de milho contendo $26 \%$ de umidade. SRIVASTAVA e MOWAT (1980), utilizando também grãos de milho com $28 \%$ de umidade, tratados com doses de $0,1,2$ e $3 \%$ de $\mathrm{NH}_{3}$, verificaram que somente as doses de 2 e $3 \%$ foram eficientes na conservação do material.

TEIXEIRA (1990), contudo, verificou a presença de fungos em capim-elefante contendo $65 \%$ de umidade, tratado com doses de 1,5 e $3 \%$ de amônia anidra. CAMPOS (1994) reportou que a dose de $1 \%$ de $\mathrm{NH}_{3}$ não foi eficiente na conservação do feno de alfafa com alta umidade, e sim as de 1,5 e $2 \%$ de $\mathrm{NH}_{3}$.

Melhor conservação da silagem de milho após abertura foi verificada por BUCHAMAN-SMITH (1982), ao proceder à aplicação de $1 \%$ de $\mathrm{NH}_{3}$. Foi observado também aumento de $40 \%$ no conteúdo de ácido lático.

A variação de temperatura na quirera de milho, em função de diferentes períodos de aeração, é apresentada na Figura 7. As temperaturas foram mais elevadas nas doses de 0 e $1 \%$ de $\mathrm{NH}_{3}$, enquanto, nas demais doses (2 e 3\%), as temperaturas foram menores e menos variáveis. Essa elevação da temperatura, para as doses de 0 e $1 \%$, deve-se provavelmente à atividade de fungos e bactérias, ocorrida na quirera com alta umidade, enquanto a menor variação da temperatura, apresentada para as doses de 2 e $3 \%$, mostra a eficiência da $\mathrm{NH}_{3}$ na conservação da quirera. 


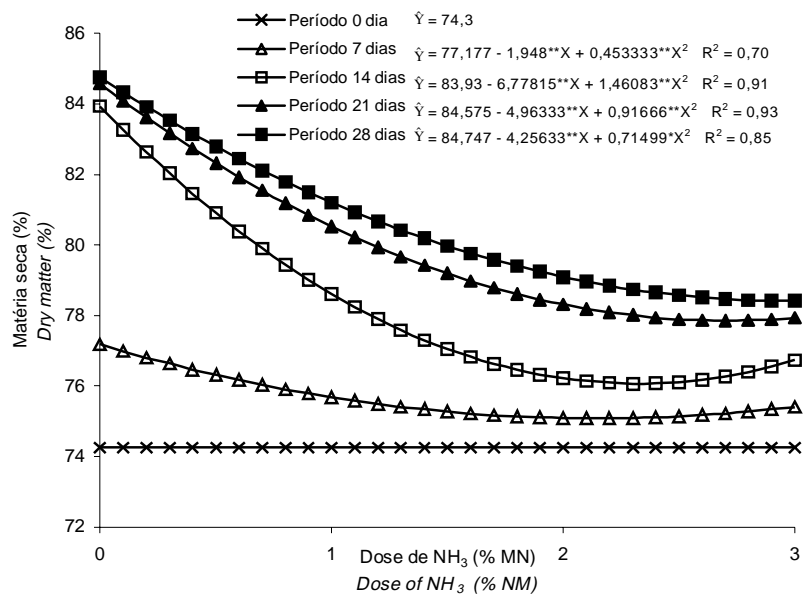

Figura 5 - Estimativas dos teores médios de matéria seca (MS), na quirera de milho com alta umidade, em função de doses de amônia anidra.

Figure 5 - Estimates of dry matter (DM) average contents in the cracked corn with high moisture, in function of doses of anhydrous ammonia.

Resultados semelhantes foram verificados por RUSSEL et al. (1988), ao tratarem com uréia grão de sorgo contendo alta umidade.

Verificou-se efeito significativo de doses de amônia anidra $(\mathrm{P}<0,01)$, não sendo verificado efeito para períodos de aeração, interação de doses de amônia e período de aeração para a variável FDN e hemicelulose.

Verificou-se que, para as doses de 0 e $1 \%$ de amônia anidra, o teor de FDN variou, em média, de 22,7 a $22,8 \%$. No entanto, para as doses de 2 e $3 \%$, observou-se queda, sendo que os valores médios para as respectivas doses foram de 18,2 e 14,8\%, correspondendo à queda de 20,4 e $35,2 \%$, em que o período de aeração não teve efeito sobre a variável (Figura 8).

Para os teores percentuais médios de hemicelulose, observa-se fato semelhante ao ocorrido com a FDN, em razão de não se detectar efeito das doses de 0 e $1 \%$ de amônia anidra, sobre o teor de hemicelulose da quirera, sendo os valores 17 e 17,3\%. As alterações ocorreram em função das doses de 2 e $3 \%$, em que os valores médios encontrados foram de 12,7 e 9,2\%, respectivamente (Figura 8).

Estes resultados estão de acordo com os de OLIVEROS et al. (1993), que, aplicando $3 \%$ de $\mathrm{NH}_{3}$ em pés de milho com $35 \%$ de umidade, observaram redução nos teores de FDN e hemicelulose. Os teores de FDN encontrados para os tratamentos testemunha e $3 \%$ de $\mathrm{NH}_{3}$ foram 90 e $78,4 \%$ e os de

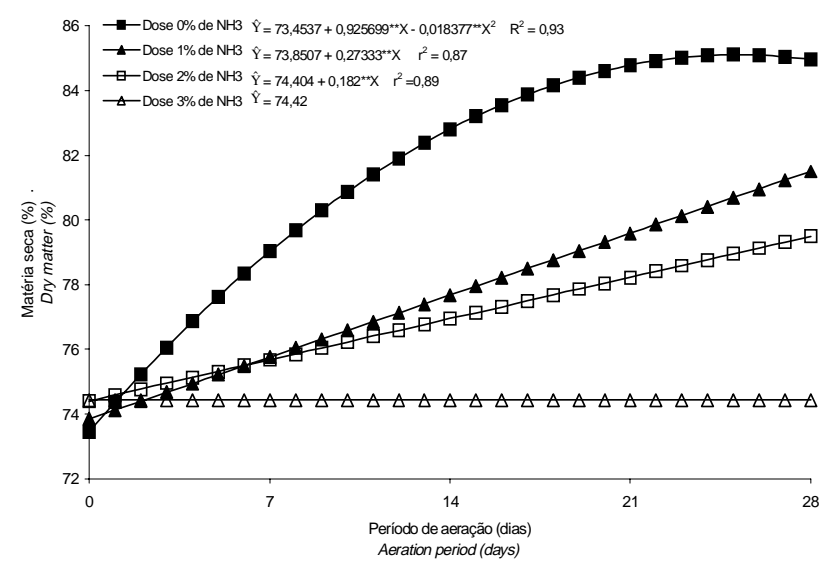

Figura 6 - Estimativas dos teores médios de matéria seca (MS), na quirera de milho com alta umidade, em função dos períodos de aeração.

Figure 6 - Estimates of dry matter (DM) average contents in the cracked corn with high moisture, in function of aeration periods.

hemicelulose, 38,1 e 25,5\%, o que está de acordo com os dados deste trabalho.

Decréscimos nos teores de FDN e hemicelulose foram, também, registrados por FERREIRA (1989), ao utilizarem três doses de $\mathrm{NH}_{3}(0,2$ e $4 \%)$, aplicados em feno de alfafa com alta umidade.

Como a maioria dos trabalhos, na presente pesquisa verifica-se que a amonização promoveu a solubilização da hemicelulose, refletindo em conseqüente queda dos constituintes da parede celular (FDN). Esse fato pode ser verificado em razão da não alteração de outros componentes da parede, como celulose e lignina, que são obtidos a partir da determinação de FDA. Os teores médios de fibra em detergente ácido (FDA) e celulose na quirera de milho foram, respectivamente, de 5,6 e 4,5\%, não sendo verificado efeito de doses, períodos de aeração e interação para as variáveis estudadas (Figura 8).

Devido ao baixo teor de lignina contido no material utilizado, as determinações ficaram difíceis, porém foram encontrados teores inferiores a 1,2\% desta variável.

Ao se submeterem os dados de digestibilidade in vitro de matéria seca (DIVMS) à análise de variância, detectou-se efeito $(\mathrm{P}<0,01)$ de doses de amônia. Os valores percentuais médios da DIVMS são verificados na Figura 9, na qual se observa que, apesar do efeito de doses de amônia, a variação da DIVMS foi pequena. Essa baixa variação pode ser explicada pela alta digestibilidade do material de origem. 


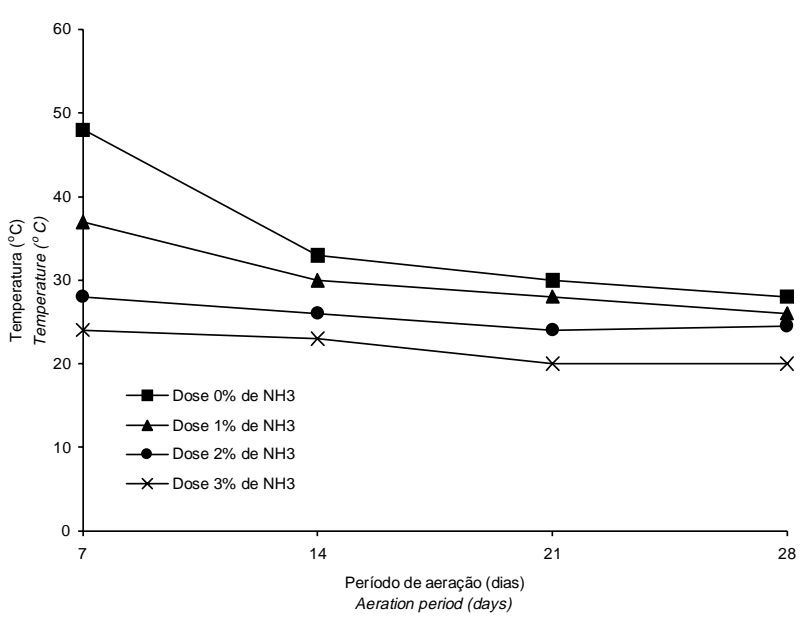

Figura 7 - Variação da temperatura da quirera de milho com $25 \%$ de umidade submetida a diferentes doses de amônia anidra e períodos de aeração.

Figure 7 - Change of temperature of cracked corn with $25 \%$ of moisture, submitted to different doses of anhydrous ammonia and aeration periods.

Os valores médios para DIVMS não variaram muito, 88,5 a 90,8\% para doses de amônia, em razão de ter sido adotado o método de duas etapas para se fazer análise da DIVMS, o que permite encontrar resultados mais elevados e menos diferenciados. OJI et al. (1977) não encontraram diferenças quando aplicaram doses de 3 e $5 \%$ de $\mathrm{NH}_{3}$ em pés de milho (50\% de umidade), sendo encontrados valores percentuais médios da DIVMS de 60,1 e 60,3\%, que foram superiores ao controle, 51,6\%.

A amonização de resíduos, em geral, promoveu aumentos na DIVMS de $13 \pm 5,5$ pontos percentuais e, com a adição de fontes de enxofre, esse aumento pode ser maior (FAHMY e KLOPFENSTEIN, 1994). Esses autores registraram aumentos de 16,7 pontos percentuais (correspondentes a 37,3\% de aumento) na DIVMS, ao tratarem pés de milho (60\% de umidade) com $6,6 \%$ de uréia mais $5 \%$ de $\mathrm{SO}_{2}$. Resultados semelhantes foram encontrados por HARGREAVES et al. (1984), que utilizaram, também, pés de milho (70\% de umidade) tratados com 2,5\% de amônia anidra, sendo registrados aumentos de 14,1 pontos percentuais (equivalentes a $35 \%$ de aumento).

Aumentos de 17 pontos percentuais (correspondentes a $35 \%$ de aumento) na DIVMS foram encontrados por DRYDEN e LENG (1986), ao aplicarem 4,5\% de amônia anidra em palha de cevada com alto teor de

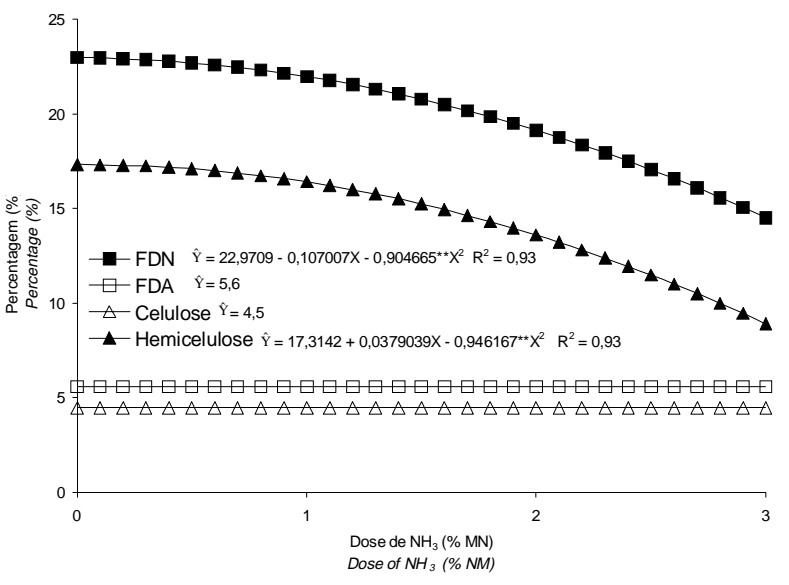

Figura 8 - Estimativas de teores médios de fibra em detergente neutro (FDN), hemicelulose, fibra em detergente ácido (FDA) e celulose, na quirera de milho com alta umidade, em função das doses de amônia anidra.

Figure 8 - Estimates of average contents of neutral detergent fiber (NDF), hemicellulose, acid detergent fiber (ADF) and cellulose in cracked corn with high moisture, in function of doses of anhydrous ammonia.

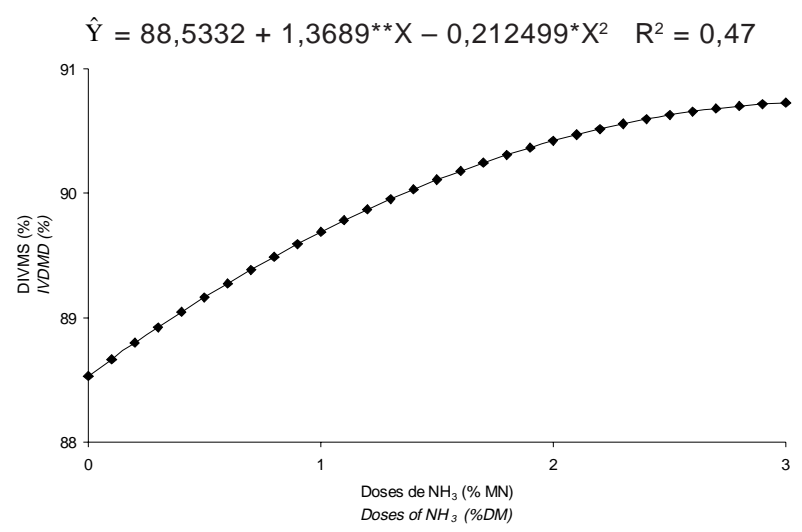

Figura 9 - Estimativa da digestibilidade in vitro da matéria seca (DIVMS), da quirera de milho com alta umidade, em função de doses de amônia anidra.

Figure 9 - Estimates of in vitro dry matter digestibility (IVDMD) in cracked corn with high moisture, in function of doses of anhydrous ammonia.

umidade. Entretanto, FERREIRA (1989) encontrou aumentos de 8,1 pontos percentuais (equivalentes a $12,5 \%$ de aumento), quando utilizou feno de aveia com alta umidade $(33,4 \%)$, tratado com $4 \%$ de $\mathrm{NH}_{3}$.

A maioria desses trabalhos difere do presente, em razão de os materiais utilizados possuírem digestibilidade menor, que pode ser aumentada em função da aplicação de produtos alcalinos. Entretanto, fatores como a 
natureza do material a ser tratado são de extrema importância, ou seja, quanto melhor a qualidade do material, menor será a resposta e vice-versa.

\section{Conclusões}

A amônia anidra pode ser utilizada na conservação e no controle da temperatura da quirera de milho com alta umidade, com aumentos do teor de proteína bruta nas doses de 2 ou 3\%. Devido à pequena variação do teor de PB nas doses estudadas, recomenda-se a aplicação de $2 \%$ de amônia anidra, por conservar satisfatoriamente o material com alta umidade e apresentar maior retenção de nitrogênio.

A amônia anidra nas doses de 2 e $3 \%$ provocou queda nas frações de FDN e hemicelulose, entretanto, os teores de FDA e celulose permaneceram constantes. Verificou-se aumento, embora pequeno, na DIVMS com as doses crescentes de amônia anidra.

\section{Referências Bibliográficas}

BOTHAST, R.J., LANCASTER, E.B., HESSLTINE, W. 1973. Ammonia kills spoilage molds in corn. J. Dairy Sci., 56(2):241-5.

BROWN, W.F., PHILliPS, J.D., JONES, D.B. 1987. Ammoniation or cane molasses supplementation of low quality forages. J. Anim. Sci., 64(4):1205-14.

BUCHAMAN-SMITH, J.G. 1982. Preservation and feeding value for yearling steers of whole plant corn ensiled at 28 and $42 \%$ dry matter with and without cold flow ammonia treatment. Can. J. Anim. Sci., 62(1):173-80.

CAMPOS, M.C.L. Níveis de amônia anidra e períodos de amonização sobre a composição químico-bromatológica e degradabilidade dos fenos de alfafa (Medicago sativa L.) $e$ coastcross (Cynodon dactylon (L.) Pers. cv coastcross) com alta umidade. Viçosa, MG, UFV, 1994. 130p. Dissertação (Mestrado em Zootecnia) - Universidade Federal de Viçosa, 1994.

DRYDEN, G.M., LENG, R.A. 1986. Treatment of barley straw with ammonia and sulphur dioxid gases under laboratory conditions. Anim. Feed Sci. Technol., 14(1/2):41-51.

FAHMY, S.T.M., KLOPFENSTEIN, T.J. 1994. Treatment with different chemicals and their effects on the digestibility of maize stalks. 2. Intake and in vivo digestibility as affected by chemical treatment and monensin supplementation. Anim. Feed Sci. Technol., 45(3/4):309-16.

FERREIRA, J.Q. Efeito da amônia anidra sobre a qualidade da palha de arroz (Oryza sativa L.) e do feno de aveia (Avena strigosa Schreb.). Viçosa, MG, UFV, 1989. 110p. Tese (Doutorado em Zootecnia) - Universidade Federal de Viçosa, 1989.
GARCIA, R. Amonização de forragens de baixa qualidade e a utilização na alimentação de ruminantes. In: SIMPÓSIO UTILILAÇÃO DE SUBPRODUTOS AGROINDUSTRIAIS E RESÍDUOS DE COLHEITA NA ALIMENTAÇÃO DE RUMINANTES, São Carlos, SP. 1992. Anais... São Carlos, EMBRAPA/UEPAE, 1992, p.83.

GOTO, M., YOKOE, Y., TAKABE, K. et al. 1993. Effects of gaseous ammonia on chemical and structural features of cell walls in spring barley straw. Anim. Feed Sci. Technol., 40:207-21.

HARGREAVES, A., HUBER, J.T., ARROYOLUNA, J. et al. 1984. Influence of adding ammonia to corn stalklage on feeding value for dairy cows and on fermentation changes. $J$. Anim. Sci., 59(3):567-75.

MOWAT, D.N., McCAUGHEY, P., MACLEOD, G.K. 1981. Ammonia or urea treatment of whole high moisture shelled corn. Can. J. Anim. Sci., 61(3):703-11.

OJI, U.I., MOWAT, D.N., WINCH, J.E. 1977. Alkali treatments of corn stover to increase nutritive value. J. Anim. Sci., 44(5):798-802.

OLIVEROS, B.A., BRITTON, R. A., KLOPFENSTEIN, T.J. 1993. Ammonia and/or calcium hidroxide treatment of maize stover: intake, digestibility and digestion kinetics. Anim. Feed Sci. Technol., 44(1/2):59-72.

PAIVA, J.A.J. Níveis de amônia anidra, períodos de amonização e de aeração sobre a composição químico-bromatológica e a degradabilidade "in situ" da palha de milho (Zea mays L.). Viçosa, MG, UFV, 1992. 162p. Tese (Doutorado em Zootecnia) - Universidade Federal de Viçosa, 1992.

RUSSEL, R.W., LIN, J.C.M., THOMAS, E.E., MORA, E.C. 1988. Preservation of high-moisture milo with urea: grain properties and animal acceptability. J. Anim. Sci., 66(8):2131-9.

SAENGER, P.F., LEMENAGER, R.P., HENDRIX, K.S. 1982. Anhydrous ammonia treatment of corn stover and its effects on digestibility, intake and performance of beef cattle. $J$. Anim. Sci., 54(2):419-25.

SILVA, D.J. 1990. Análise de alimentos (Métodos químicos e biológicos). Viçosa, MG, UFV: Impr. Univ. 165p.

SRIVASTAVA, V.K., MOWAT, D.N. 1980. Preservation and processing of whole high moisture shelled corn with ammonia. Can. J. Anim. Sci., 60(3):683-8.

TEIXEIRA, J.R.C. Efeito da amônia anidra no valor nutritivo da palha de milho mais sabugo e do capim-elefante (Penninsetum purpureum shum.) cv cameroom fornecidos a novilhos nelore em confinamento. Viçosa, MG, UFV, 1990. 97p. Dissertação (Mestrado em Zootecnia) - Universidade Federal de Viçosa, 1990.

Recebido em: 05/06/98 Aceito em: 07/07/99 